\title{
Exploring the foundations of the intercultural policy paradigm: a comprehensive approach
}

\author{
Ricard Zapata-Barrero \\ (Received 19 February 2014; final version received 8 January 2015)
}

\begin{abstract}
In this second decade of the twenty-first century, interculturalism is emerging as a new policy paradigm to deal with diversity dynamics. It is basically viewed as a set of policies sharing one basic idea: that the interaction among people from different backgrounds matters. Its concerns are to intervene politically and to propose a way to manage the dynamics of diversity, based on exchange and interpersonal relations. I propose exploring a foundational internal debate, based on the premise there are at least three different, but complementary, normative strands: contractual, cohesion and constructivist strands. My ultimate purpose is to defend a comprehensive view, grounded on the argument that no one can have the sole authority to define intercultural policy, since the three strands can be applied at different moments, according to different purposes. The challenge is for policy managers to be able to achieve a balance between the three policy drivers.
\end{abstract}

Keywords: interculturalism; immigrants; citizens; diversity; policy; cities

\section{Some preliminaries: the academic and diversity policy context}

In this second decade of the twenty-first century, interculturalism is emerging as a new policy paradigm to deal with diversity dynamics. It is at the centre of policy and academic debates, and expresses the intention of influencing governments to reconsider their approaches to diversity, especially at the city level. For instance, in 2008, the European Year of Intercultural Dialogue was established, setting the framework for the recognition of cultural diversity and the intercultural approach within the European Union's agenda. ${ }^{1}$ Along this line, the Council of Europe and the European Commission gave their endorsement that successful cities and societies of the future would be indeed intercultural - a visible approach in the joint action called the Intercultural cities programme, in which more than 60 cities are involved. ${ }^{2}$

Interculturalism can be seen as a set of policies sharing one basic idea: that the interaction among people from different backgrounds matters. Its concerns are to intervene politically and to propose a way to manage the dynamics of diversity, based on exchange and interpersonal relations, using what I call the 'technique of positive interaction' to ensure a favourable public 
environment for intercultural contact (Zapata-Barrero, forthcoming). Despite the many conferences and policy meetings devoted to this topic, there are still only a few internal disputes. It has already received reactions from multiculturalist academics, such as Meer and Modood (2012), who argue that there are far more similarities than differences between the two paradigms. Moreover, they charge that interculturalism may harbour misconceptions regarding multiculturalism, such as its fixed, group-based view of culture. The volume recently edited by Barrett (2013) moves in the same direction by examining the similarities and differences between these two policy approaches. At any rate, the debate is now wide open in Europe and elsewhere. ${ }^{3}$ Given this framework of discussion, I propose exploring the main basis of a foundational internal debate.

We confront a policy strategy of managing diversity that promotes a process of building a common public sphere in a 'living together context' (Hogan 2011). We also find ourselves in a context that lacks convincing public policies dealing with the reality of super-diversity (Vertovec 2007, 2014). Seen basically as an urban phenomenon, there is an institutional recognition that diversity can be a driving force in reshaping the city's public culture. From this perspective, it is assumed that diversity is itself a culture that should be promoted through an intercultural strategy, influencing knowledge construction and prejudice reduction (Zapata-Barrero, forthcoming) and even serving as a tool to reduce the space of xenophobic discourses (Zapata-Barrero 2011).

There is a vast literature showing how public spaces are places where people form new relationships with people from other cultures, and that most of the time they are interclass and intergenerational (Wood, forthcoming). Interculturalism is seen as encouraging the promotion of sociability, cohesion, cooperation and a sense of community (Bagwell et al. 2012). In this article, I claim that, in spite of having one core concept of interculturalism, there are, nonetheless, at least three basic conceptions, which need not be interpreted as being at odds, but rather as complementary angles of the same intercultural concern: contractual cohesion and constructivist strands. I will thus follow two steps in my argument. The first is to consider how the first two conceptions share a rights-based approach towards individuals, along with a communitybuilding concern for ensuring a common public sphere. I will attempt to contrast this with an approach based on agency and capability, which is directly concerned with people's motivations to interact and their individual development. I will call this conception the constructivist strand. The second step of my argumentation will attempt to defend a comprehensive view, grounded on the argument that no one can have the sole authority to define intercultural policy, since the three strands can be applied at different moments, according to different purposes. The next challenge is for policy managers to be able to achieve a balance between the three policy drivers. 


\section{What is the common core of the intercultural approach? Two shared premises}

My initial concern is to identify what is the common core of the intercultural approach. The first premise is undoubtedly the 'critique of multiculturalism'. ${ }^{4}$ Its point of departure is the diagnosis that multicultural policies in past decades have missed an important point: interaction between people from different cultures and national backgrounds.

This is a fact that even the liberal multicultural scholar Kymlicka recognises, stating that 'we have multicultural states populated by citizens who have only minimal levels of intercultural interaction or knowledge' (2003, 155). He continues, '[W]e should encourage individuals to have the ability and desire to seek out interactions with the members of other groups, to have curiosity about the larger world, and to learn about the habits and beliefs of other peoples' $(2003,158)$. The core meaning of interculturalism is etymologically related - that is, it means to act together with a common purpose, sharing a public sphere and working for some common purpose. Contrary to multiculturalism, which focuses on people's cultural rights and thus has an initial understanding of interpersonal comparisons that is centred in what is different rather than similar (the seminal work remains Kymlicka 1995; also Parekh 2000), the clue to grasping interculturalism is that it is not based on an individual or a group agent, but is rather a strategy to manage a dynamic process of interaction based in what is common. This collaborative action can only be accomplished if people feel free to act, as human beings, without being categorised in terms of diversity by some administration or policy that encapsulates them according to any particular attribute (religion, language, nationality or even continent). Interculturalism emphasises then what is (or can be) shared between people or groups, rather than exhibiting what is unique and 'must be recognised and respected' among people who see each other in terms of 'otherness'.

It is due to this primary focus that interculturalism points to the common humanity that emerges from interactions. Interculturalism fundamentally proposes, then, a change of focus: the policy lens moves from a static, centred point (an approach based on an individual or group agent) to a much more dynamic and multidirectional process, one that results from interpersonal contact. Interculturalists agree on the backlash of multiculturalism literature (Vertovec and Wessendorf 2009; Pakulski and Markowski 2014), which has been charged with causing self-segregation and with engendering more inequality and separation among people of different cultures. But we cannot generalise, since multiculturalism is a heavily debated concept, to the point that it is perhaps most appropriate to speak of 'multiculturalisms'. This 'multicultural question', however, is not new. From the beginning, the link between multiculturalism and equality has been disputed, in terms of the social consequences of policies recognising cultural differences. The most 
seminal normative argumentation still remains Barry's (2001) egalitarian criticism of the politics of multiculturalism. I also quote Hall (2000, 235), who aptly summarises: 'How then can the particular and the universal, the claims of both difference and equality, be recognised? This is the dilemma, the conundrum - the multi-cultural question - at the heart of the multi-cultural's transruptive and reconfigurative impact'. The normative discussion of the multicultural literature always attempts to rectify the consequences of increasing marginalisation that emerges from social and political structures. It focuses on the principle of equality, understood as redistribution of wealth and recognition of cultural rights (Frazer and Honneth 2003). Surely, within this criticism of social egalitarianism, the Cantle report (2001) stands as one of the great efforts to deal with conflictive empirical evidences, at a time when the UK suggested that it was the lack of social cohesion that led to northern city tensions in 2001 (in Bradford, Oldham, Burnley and Leicester), paving the way for less multicultural policies, while increasing uneasiness regarding the supposed segregation of minority communities.

This criticism of multiculturalism is carried out with two foundational weapons: first, the individual prevails over the group. Second, culture cannot be an iron cage - either in regards to the freedom of people who do not want to be typified by origin, or in respect to institutions that fail to ensure the system of rights and duties, to distribute goods and services or to incorporate origin or nationality as a criterion. ${ }^{5}$ In both regards, interculturalism presents itself as a framework that tries to challenge the way multiculturalism(s) have always tended to categorise people through origin and nationality, which predetermine certain behaviours and beliefs. Interculturalists seek to break this essentialist view of diversity. Thus, they endorse this detachment from any attempt to align culture with genetics, as though it were hereditary like skin colour (Bloomfield and Bianchini 2001, 104). We can also include here Phillips' (2007) multiculturalism without culture argument, in which she claims that it is time to elaborate a version of multiculturalism that dispenses with reified notions of culture, in favour of a version that engages more ruthlessly with cultural stereotypes. These substantial criticisms are very close to what Brubaker calls 'groupism', namely, 'the tendency to treat ethnic groups, nations and races as substantial entities to which interests and agency can be attributed' (2002, 164).

Individual preferences and practices, rather than national origin ascriptions, prevail as a policy framework. Let me give an example: to be of Moroccan origin does not entail being Muslim and following Islamic beliefs. It would be the same if I refused to be ascribed as Christian in Morocco, but was nonetheless subjected to certain multicultural policies because of this institutional prejudgement. In a nutshell, what interculturalists claim is that we must let people decide their cultural practices, their religions and their languages, independent of the national circumstances into which they were born. Interculturalism is about first asking how people recognise their 
identities, and it then respects their self-identification. This also includes a respect for the diversity of identities within the same national-cultural category. I am thinking, for instance, that even if Morocco does not officially recognise cultural diversity among their own nationals (for instance, Amazigh or Berber culture), multiculturalism contributes to this homogenisation of Moroccan culture by being too nationality-dependent in ascribing the cultural identities of people of Moroccan origin.

The second premise rests on the view that interculturalism is mainly a policy intervention in diversity dynamics. Thus, the key question for us is how to justify intervention (or, formulated in another way, how to justify intercultural promotion), rather than leaving the deployment of diversity to be carried out socially. The answer to this foundational concern rests on three empirical hypotheses, emerging from literature that focuses on the potential impacts of diversity without policy intervention.

(1) The political hypothesis argues that diversity tends to alter the traditional expression of national identities, threatening traditional values and the system of relations of rights and duties, which ensure a common sense of loyalty and stability between citizens and the basic structure of society. In this case, the technique of interaction seeks to maintain control of any justified change in traditional national values, protecting equilibrium between the loyalty of citizens and the rights of immigrants (see, for instance, Bouchard 2012).

(2) The social hypothesis says that diversity tends, at the beginning of the process, to provoke segregation and exclusion, and it reduces social capital and the sense of belonging in society, either through social inequalities or through the interference of information and knowledge among immigrants and citizens (see, for instance, Putnam 2007). Interculturalism seeks to restore social cohesion, trust and feelings of belonging (Cantle 2012), through social equality policies, in addition to policies that try to promote knowledge formation and prejudice reduction (Zapata-Barrero, forthcoming).

(3) The cultural hypothesis rests on the view that citizens' and immigrants' cultural capabilities are not fully developed in a diverse society. Here, I refer not only to nationality-based culture, but also to cultural citizenship in general (Turner 2001). Left alone, diversity tends to close off cultural opportunities. Interculturalism seeks to promote the development, creativity and innovation in diverse societies (see, for instance, Bennett 2001).

My next step is to enter into this internal debate of interculturalism and to argue that there are currently three basic strands, with quite different dividing lines. 


\section{Three normative policy drivers of interculturalism}

If we consider the three basic hypotheses justifying intercultural promotion, we have indeed three kinds of potential interactions. First, there is a horizontal one among all the members of society, understood multidirectionally - that is, among immigrants, among citizens, and among immigrants and citizens (this is the basis of the social hypothesis). Second, there is a vertical one between immigrants and the basic structures of the society (the basis of the political hypothesis); while the third is a deepening of interpersonal development and personal cultural abilities (the basis of the cultural hypothesis). In this section, I argue that each hypothesis develops a theory that informs a distinct intercultural strand.

To react to the political hypothesis, we need to develop a political theory of diversity. I take as the most recent illustration of this view the work of Bouchard (2012), which is essentially centred on managing the relationship between immigrants and the basic structures of society, ensuring what Bouchard calls 'the survival of national identity'. 6 It seeks to provide the most appropriate spaces for motivating agreements between national tradition, which accepts unavoidable changes, and the context of diversity, through participative policy channels and other means of vertical communication. Its purposes are to manage the potential impact that changes can have on tradition, to regulate the behaviour of nationals and to minimise impacts on the loyalty of citizens and the rights and duties of immigrants (especially regarding equal opportunities).

Answering the social hypothesis requires the development of a social theory of diversity, grounded in Allport's (1954) well-known contact theory (which, more or less, states that contact reduces prejudice and promotes knowledge formation), and based on Cantle's (2008) view of interculturalism as community cohesion. Supporting positive interaction involves transforming initial conflict zones into areas of positive contact, in order to ensure an optimal living situation. Its basic aim is social conflict reduction, as diversity becomes an explanatory factor of social disturbances. Moreover, conflict is a broader notion encompassing racism, poverty and social exclusion (Cantle 2012, 102). The promotion of social participation and the incorporation of immigrants into the main social networks of the city are also main priorities in fostering cohesion.

Lastly, if we want to formulate policy reactions to the cultural hypothesis, we need to frame a cultural theory of diversity, based on promoting the cultural capabilities of people, which is to be understood in terms of the cultural goods and resources needed to develop creative and innovative practices in society. This theory rests on a particular application of the diversity advantage literature already informing most of the diversity debate in Europe and elsewhere, emerging primarily from urban and management studies. ${ }^{7}$ Interculturalism is a way to produce something new as a product of interaction, which helps the cultural development of persons qua citizens.

Graphically speaking, the social theory of diversity shapes a cohesion strand of interculturalism and has as a normative policy driver the category of cohesion 
(of social inclusion and trust), with social conflict as its basic 'diversity limit'. The political theory of diversity seeks to legitimate a contractual strand of interculturalism, having stability (of tradition and rights/duties) as its normative policy driver and the loss of national identity as its basic 'diversity limit'. Finally, the cultural theory of diversity is grounded in a constructivist strand of interculturalism. It has development (of capabilities, innovation and creativity) as its normative policy driver and the lack of equal capabilities (personal and social) as its basic 'diversity limit'.

In this debate on the foundation of interculturalism, there are, then, three angles within the same intercultural triangle (see Figure 1). It is this comprehensive view of the intercultural policy paradigm that I will try to defend. Let us look at each of these angles.

(1) Tradition/stability/diversity nexus: The contractual strand understands interculturalism as a function for enhancing stability in a diverse society, with tradition expressing itself through collective routines and socially acceptable behaviour. It designates a set of established values and beliefs transmitted from generation to generation (Friedrich 1972, 18), which can be interpreted as jeopardised by diversity dynamics, or

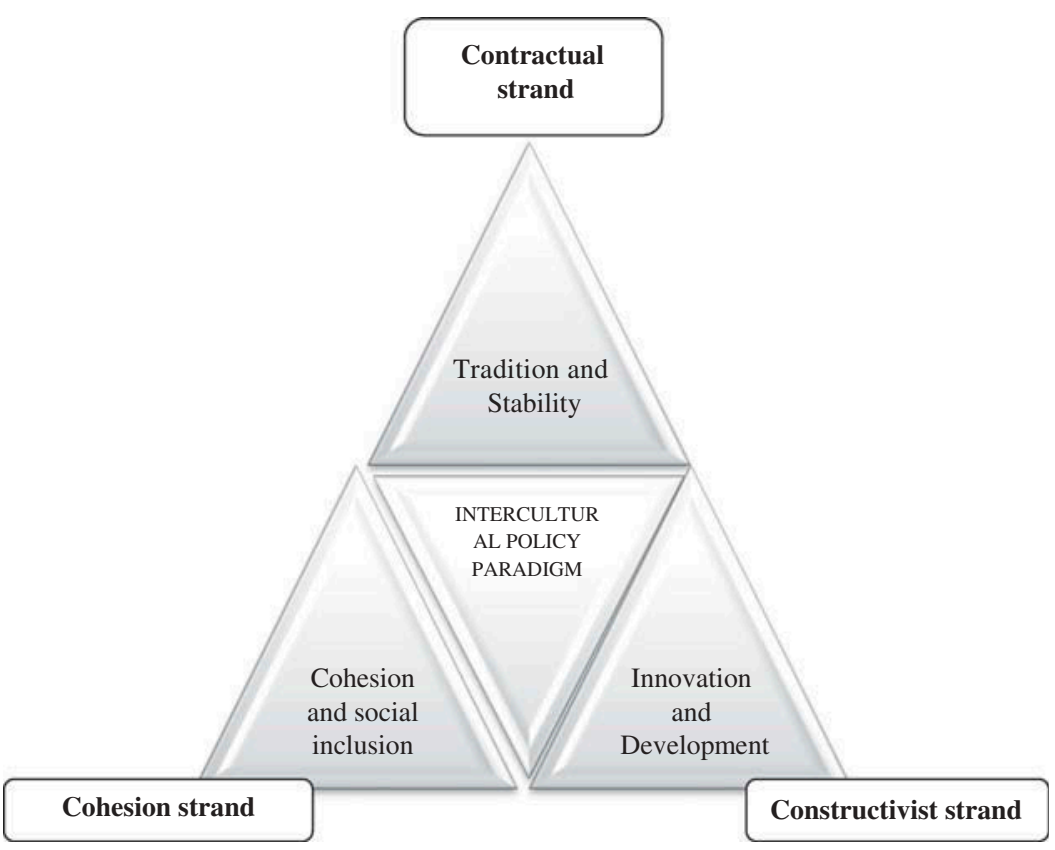

Figure 1. A comprehensive view of interculturalism: three normative policy drivers. 
as Weber conceptualised with the suggestive expression, "what has always existed' $(1968,29)$. In politics, tradition is a framework for the unity of a community of citizens, and it is a tool for promoting a sense of loyalty, thus ensuring the preservation of social values. This does not mean that the contractual strand is against any change in traditional identity, but it contends rather that this cannot suppose a loss of power of the majority/minority nexus. There are, then, two constant concerns in the contractual intercultural view: the survival of the national identity and respect for the rights of minorities. Hence, this contractual strand could also be labelled as liberal nationalism, as clearly defended by, among others, Miller (2008). For instance, the basic pillar of Bouchard's contractual view as equilibrium rests on this point. He insists, once and again, that this framework must not be interpreted in conflictive terms, but rather as a dynamic equilibrium of contact. The presence of minorities means that all forms of expressions of difference become defined in relation to the Quebecois culture or founder majority. Bouchard says categorically that the majority/minority framework in Quebec seems unavoidable and non-negotiable as a category for analysis (Bouchard 2012, 162, 167).

(2) Cohesion/social inclusion/diversity nexus: The cohesion strand understands interculturalism as a tool for managing the social inclusion/ dynamics of diversity nexus. It sees intercultural policies as a way to promote community cohesion (Cantle 2001). In contrast with the contractual strand, the British author builds his arguments without any national concern since England upholds state mechanisms already in place to deal with national protection. This is not to say that there is not a debate on Britishness, but it is not considered by the cohesion view. ${ }^{8}$ The basic worries are, rather, social conflict and segregation, due chiefly to the lack of communication among different expressions of diversity (including the national citizenship one). The intercultural strategy is interpreted as a policy mechanism for generating trust and mutual understanding and for breaking down prejudices, stereotypes and the misconceptions of others. We can say it is a technique of bridging and bonding differences and social capital (Gruescu and Menne 2010, 10). It is a way, then, to avoid the confinement and segregation of people, which, as a last resort, become explanatory variables of social exclusion and social inequality, especially in neighbourhoods and cities. ${ }^{9}$

The cohesion strand addresses power relations, as well, particularly in terms of tackling inequalities, both in opportunities and in outcomes. The purpose here is to work on the pre-conditions of mutual respect prior to intercultural dialogue, such that 'contact' is more likely to be effective (Allport 1954; Hewstone et al. 2007). 
Therefore, in contrast to the contractual strand, it promotes better faceto-face relations, step by step, in a context of proximity. Cantle, for instance, explicitly speaks about local identity and belonging campaigns to garner a sense of solidarity. We might say that while feelings of common values were the connection during past periods, it is now necessary to focus on a common space of interaction and a common citizenship (Kymlicka 2003, 195). From the perspective of the cohesion view, it tends to bridge the tension between being 'too diverse' (Goodhart 2004) and being cohesive.

(3) The innovation/development/diversity nexus: The constructivist strand understands interculturalism as a tool for managing the innovation/ dynamics of the diversity nexus. It sees intercultural policies as an instrument for promoting development in a diverse society. It is then basically a pro-active policy, in the sense that it is not a policy thought to react against any negative outcome of diversity (as a therapeutic policy), but is instead concentrated on producing a new outcome as a product of interaction. It is, then, creativity-based. This idea of construction is, then, its distinguishing characteristic. This view of diversity is perhaps best expressed by Page (2007), who states that in a problem-solving situation, heterogeneous groups have better tools to provide a variety of responses than homogeneous ones. He then provides an empirical argument for why interaction in diversity can be an asset to society. Both the former contractual and cohesion strands miss precisely this added value of diversity. This constructivist approach also has a different view of diversity, essentially considering it an asset. From this point of view, interculturalism can be then considered a strategy that promotes a context of mutual development. ${ }^{10}$

This constructivist view takes a step forward, in the sense that it promotes the cultural capabilities of people. This capability approach of diversity obviously has a direct impact on some categories of the other two interpretative strands. First of all, it sees persons not only as nationalities (as in the contractual strand), or simply as common human beings (as in the cohesion strand), but as capable agents. Following Faist's (2009) suggestive analysis of the diversity category, this involves people not only being considered in terms of their rights, but also in terms of what they can do and are able to achieve. We take into consideration, then, individual skills (what an individual knows how to do) and competences (what an individual is capable of doing). In fact, this view has the feature of giving answers to a question the contractual and cohesion strands have not even posed, and which seems to me commonsensical. It is not a question focused on the function of interculturalism, such as why positive interaction matters, but rather concerns the incentives of people to interact. Namely, how are people motivated to interact? It is fair to recognise that in spite of sharing the core concept interculturalism $=$ positive interaction $=$ reciprocal contact , each strand 
has different notions of what interaction assumes and means in social and functional terms.

\section{What does interaction mean?}

For the contractual strands, 'interaction' is basically conceived in vertical terms, between a founding majority culture and a diverse culture of minority newcomers. In this view, interaction is viewed in a one-dimensional manner, having a homogeneous view of both parts of the interaction (national citizens vs. diverse immigrants). In contrast, for the cohesion strand this interaction is basically understood in horizontal terms. It is always multidimensional and complex, without any pre-categorisation of the population, and it thus breaks away from the strand that differentiates the population in dualistic terms between an usmajority-national-citizen and a minority-other-diverse-immigrant.

Ultimately, the contractual view seems to promote some sort of reconciliation between a national majority and a diverse minority. ${ }^{11}$ As a guiding thread in this line of thought, Bouchard $(2012,64)$ insists that interculturalism commits majority/minority in an opening and reconciliation dynamic rather than retrenchment and tensions'. ${ }^{12}$ Here, the key question is how to attenuate the dualism respecting the rights of persons: interculturalism is always understood as a way to arbitrate conflicts and divisions, as a way to promote living together in a divided society (Bouchard 2012, 89).

Definitively, for both the cohesion and the contractual strands, interculturalism is understood as a tool for preventing national divisions (contractual strand) and social conflicts (cohesion strand). The new members of a society, arriving by way of immigration, sometimes challenge the actions and routine patterns of public conduct of tradition; they can, therefore, be perceived as potential threats to tradition (the contractual strand). These new members can also be new factors of poverty and exclusion, and so diversity itself becomes an explanatory factor in social inequality and separation, affecting cohesion and the sense of belonging (the cohesion strand).

Nonetheless, the constructivist strand sees this new population as an opportunity for innovation and creativity. In contrast with the two previous views, diversity is now seen as a public good and a resource that needs to be managed positively. As such, diversity becomes an opportunity for individual and social development. This view is not new, but belongs to the diversity advantage promoted by the joint programme between the Council of Europe and the European Commission called Intercultural cities in 2008. Incorporating this third angle of interculturalism, we can say graphically that stability (of tradition, rights), cohesion (regarding social conflict, trust) and development (of capabilities, innovation and creativity) become an interpretive framework within which we can inform intercultural policies. From this point of departure, let me offer more detail regarding the constructivist view, adding some distinctive features of this strand that I think the diversity advantage literature fails to address clearly. 


\section{How are people motivated to interact? Deepening the diversity advantage approach of the constructivist strand}

One basic distinctive feature of the constructivist view is that it makes visible an assumption of the contractual and cohesion strands: the question of motivation. That is, it responds to the assumption that people will be motivated to interact. This assumption cannot be taken for granted. The constructivist view seeks, then, to encourage a link between people of different backgrounds, who have common capabilities (skills and competences), and it then views both agents as being better able to develop their own capabilities and to even provoke a creative outcome through interaction. It is this innovative product and this creative atmosphere that motivate people to interact. At the basis, there is a common interest in developing one's own capabilities. ${ }^{13}$ It is here that the category of innovation which is, in my view, absent in both previous strands - can play a prominent driving role.

This argument for considering people not only as agents of rights but also as agents of development is, from the constructivist view, furthermore related to a renewed category of equality. Compared to what it is assumed to be, according to both the contractual and the cohesion strands, equality here is not understood in material and instrumental terms ('If I have two and you have three, then we are unequal'), but rather in terms of capabilities. I draw this conception from Sen's (1992) seminal approach to equality. Here, I focus not on a view of the universal person or of the person as holder of national identity; I focus instead on personal capabilities. The definition of capability is directly linked to the equality of opportunities. This approach is built as a reaction against the utilitarian perspective that defines equality in terms of material possessions, and applies to primary goods and resources that people need to perform their particular worldviews.

The capability approach tells us that the important issue is encouraging the creation of conditions for people to have real opportunities to judge the kind of life they would like to have, and the type of person they would like to be. In this sense, enhancing autonomy of the individual to choose the life they want in terms of their cultural capabilities can rightly be considered as a new driver of intercultural policy. But what does 'capability' mean? It is defined as anything that a person can do or be. If a person has the ability to read and cannot perform this action, then there is a problem of inequality, while others with similar skills can develop this ability and exercise it (i.e. they can read). Applied to everyday life, for instance, to put people in contact who want to develop cooking skills, cultural skills or language skills is what this constructivist view of interculturalism is about. ${ }^{14}$ From this constructivist strand, intercultural policies cannot force people to interact if they do not see sufficient reasons to do so. What this interaction technique establishes is an institutional framework, a societal scenario (be it national, regional or urban) and a social space that motivates people to interact, even if, in the end, they do not. For this reason, this interaction technique is 
crucial for allowing people to develop their cultural capabilities and to construct their own ways of life and particular cultural expectations. In my view, this added value of interaction is what the other two views fail to address. It is this extra feature that motivates people because they will see that, through interaction, they will develop their cultural capacities and skills and will even develop their creativity.

From this perspective, interaction is a technique that can help to develop cultural capabilities through joint actions among people coming from different dynamics of diversity. I am speaking of personal opportunities to develop physical abilities, to nurture skills related to art, entertainment or linguistics, to explore cultural or religious concerns and capabilities, and so on. These skills are basic, yet vital, and are closely related to the ways in which people project their personal cultural life plans in a diverse society.

This constructivist strand of interculturalism holds innovation as a basic category, as distinct from tradition and social cohesion. We take this category in the most literal sense, as involving creativity, transformation, change, alteration, modification, renovation, modernisation and even performance and improvement. As opposed to tradition, it is - to modify the previous Weberian expression - promoting 'what never existed' but what can be generated through interaction processes. In contrast to cohesion, it tries to motivate people to interact because they will see that this relationship would help them develop certain cultural capabilities. This is what the different dynamics of diversity produce through interaction: something new for all agents of the interaction. Moreover, like any new component in society, it transforms the context for all involved, accommodates diversity, creates new spaces for action and alters the existing logic of action. What matters regarding innovation is, therefore, primarily the transformative effect it produces, which is absent in both the contractual and the cohesion strands.

I would even go so far as to state that diversity has, here, a subversive component, in any context where it occurs, because it challenges existing social conventions. It necessitates a structural change to modify behavioural patterns, to transform public space and to change institutional routines to be transformed back into tradition.

This raises issues, such as whether to give each culture continuity and reproduction within its own public social space, or whether we must promote interaction among them as the basis of creativity and innovation, which evolve through all cultural types, and which are continually developed and redefined. It is assumed, therefore, that all expressions of diversity have something to learn (or to contribute, depending on where we build the argument) from other expressions of diversity. Diversity expresses its own specific social meaning only through everyday practices of social interaction (Sandercock 2009, 220; Brecknock 2006, 38).

However, as I have argued, the constructivist view is just a third angle of intercultural policies since it insists on different concerns regarding diversity 
dynamics. What is most important is that these views are only complementary normative policy drivers that can be used to categorise existing local practices dealing with diversity management. Indeed, it is this comprehensive view that I will defend as the last step of my argumentation.

\section{Interculturalism: a comprehensive approach}

The comprehensive approach is the main basis for the foundations of intercultural policies. This global view holds that interculturalism is a way to manage the contractual, cohesion and constructivist normative strands. To understand this comprehensive view appropriately, we have to keep in mind that interculturalism should be performance oriented. I propose widening the focus to see all three views at the same time, as interconnected. Indeed, my strong argument is that intercultural policy, when it is implemented, should be neither the contractual, nor the cohesion, nor the constructivist view alone, but the three practices applied at different moments in the city, according to particular purposes and needs.

This interplay between tradition, cohesion and innovation is thus the framework within which we can ground the intercultural policy paradigm. They involve policies, behaviours, cultural practices, institutional routines and management programmes that help create bridges between 'what has always existed' (contractual strand), 'what generates social conflicts' (cohesion strand) and 'what it is new' (constructivist strand). It ultimately works to apply this logic of equilibrium so rightly defended by Bouchard, and this anti-exclusion logic orientating Cantle's cohesion view, but with the added value of innovation, creativity and human and social development. Without this added value, interculturalism can become, in the last resort, just a phase in the historical trajectory of diversity in society, but it will not reach the level of being a new historical policy paradigm. The real challenge of interculturalism is not to decide which of these three views is right or wrong, but to balance them in a comprehensive framework, one which considers that the techniques of interaction must create a context where tradition, cohesion and innovation drive local governments' intercultural policies. The challenge now is for local policy managers to be able to have a comprehensive view and to achieve a balance between the three normative driving forces in a context of global implementation.

\section{Acknowledgements}

This article has benefited from several discussions in different academic settings during my sabbatical year 2012-2103 in the Chaire de Recherche du Canada en Études Québécoises et Canadiennes (CRÉQC) (Département de Science Politique, Université du Québec à Montréal). I thank, first of all, A. Gagnon for several exchanges during my writing, as well as to G. Bouchard, T. Cantle and Ph. Wood, with whom I have had very direct and constructive discussions. Also, colleagues that invited me to share arguments from Concordia University (12 February 2013), D. Salée, A. Bilodeau; from Guelph University (5 March 2013), A. Guida, C. Thomson and M. Irvine; from Queens 
University (6 March 2013), K. Banting, M. Moore and O. Haklai; F. Rocher and L. Turgeon from Ottawa University (8 March 2013), and L. Seile and A. Germain from The Institute for Research on Public Policy and l'Institut National de la Recherche Scientifique, respectively (12 June 2013).

\section{Disclosure statement}

No potential conflict of interest was reported by the author.

\section{Funding}

This article is a dissemination of Diversidad project, funded by the Spanish Ministry of Economy and Competitiveness [Ref.: CSO2011-28885].

\section{Notes}

1. See http://www.interculturaldialogue2008.eu.

2. See http://www.coe.int/t/dg4/cultureheritage/culture/Cities/Default_en.asp. Likewise in 2009 the Eurofound conducted a wide-ranging study examining intercultural practices, the European network of cities for local integration policies for migrants (CLIP) (see Borkert et al. 2007; Lüken-Klaßen and Heckmann 2010, and the CLIP website: http:// www.eurofound.europa.eu/areas/populationandsociety/clip.htm). More recently, focusing specifically on intercultural policies, the European Ministerial Conference on Integration (Council of the European Union 2010), held under the Spanish Presidency, underlined once again the central role of local authorities when facing the challenges of applying intercultural and integration programmes. http://ec.europa.eu/ewsi/UDRW/ images/items/docl_13055_519941744.pdf.

3. See, in general, the entire bibliography, along with the seminal works of Gundara and Jacobs (2000), Wood (2004), Bloomfield and Bianchini (2004), Sandercock (2004), Sze and Powell 2004), Brecknock (2006), Khan (2006), Barn (2011), Clarijs et al. (2011), Emerson (2011), Farrar, Robinson, and Sener (2012), Bouchard (2012), Cantle (2012), and Taylor (2012).

4. Without entering into the discussion, a new book, addressing the normative discussions on the dividing line between interculturalism and multiculturalism, is forthcoming in 2016, edited by Meer, Modood, and Zapata-Barrero (forthcoming).

5. It can be accurately stated that this initial intercultural literature has a generalised view of multiculturalism, when we already know that there is a complex web of arguments that do not even express concerns or conceptualise groups in the same way. There are also many levels of argumentation, from the strict normative one to the most everyday experience as it has been properly conceptualised by Phillips, who argues that "the most accurate reading is probably a process of "multicultural drift" a series of smallish adjustments and accommodations that added up to a quite substantial practice of multiculturalism' $(2007,5)$. Even from the psychology, the diagnosis that there is not one but several multiculturalisms has been noted in the recommended overview by Howarth and Andreouli (2012).

6. The same Québécois academic stresses, 'Interculturalism is the better option to ensure Québec's survival' (Bouchard 2012, 229). Thus, in the context of Québec, feelings of insecurity are also fuelled by the growing presence of immigrants and cultural minorities, largely concentrated in the area surrounding Montreal. As Bouchard highlights in previous work, this feeling is justified, since it is an 
expression of the fragility of Francophone Québec in America, a condition accentuated by globalisation and by uncertainty over francisation (Bouchard 2011, 447).

7. See, among others, Blommaert and Verschueren (1998), Zachary (2003), Sze and Powell (2004), Wood (2004), Festenstein (2005), Hussain et al. (2006), Page (2007), and Wood and Landry (2008).

8. On the Britishness debate, see, for instance, Modood (2010).

9. This vision has been the driving force of CLIP (see supra note 2), as has been shown in various case studies and reports. See, among others, Valencia (Caponio 2009), Malmö (Crawly and Crimes 2009), Tallin, Wroclaw (Matusz Protasiewicz 2009a, 2009b), Turin (Ricucci 2009) and Amsterdam (van Heelsum 2010).

10. This is maybe the view best worked by the Intercultural cities programme of the Council of Europe (2011), which shows through many case studies that cities can take diversity as an asset for individual and social development. See, among others, reports on diverse cities: London (Bagwell et al. 2012), Lewisbawn (Brecknock et al. 2007) and Helsinki (Comedia 2010). Regarding Barcelona, a recent critical article has appeared in Zapata-Barrero (2014).

11. Even if this term has a quite concrete meaning for Quebecois, illustrating a way to restore past conflicts between Quebec national founders and indigenous autochthones, the term 'reconciliation' has been used in some reports within this context of immigration-related diversity. See, for instance, the same Bouchard-Taylor report (2008), whose subtitle states: fonder l'avenir. Le temps de la reconciliation (Building the Future. A Time for Reconciliation).

12. Translation by the author.

13. There is a proposed methodology, adapted to the development of local intercultural strategies, which follows this constructivist approach, taking as case studies the cities of Lisbon, Melitopol and Tilburg (Brunson 2013).

14. There are several examples, mainly at the neighbourhood level, following this view. See case studies that show how intercultural practices foster individual and social improvement in Clarijs et al. (2011). This collective book overviews diversity policy in different countries in the five continents: Europe (in the UK, Russia, France, the Netherlands, Germany, Israel, Serbia, Ukraine, Switzerland), North America (the US), South America (Chile), Asia (Japan) and Oceania (New Zealand). See, among others, the overview by Hogan (2011).

\section{ORCID}

Ricard Zapata-Barrero (1) http://orcid.org/0000-0002-3478-1330

\section{References}

Allport, G. 1954. The Nature of Prejudice. Cambridge: Addison Wesley.

Bagwell, S., G. Evans, A. Witting, and K. Worpole. 2012. Public Space Management: Report to the Intercultural Cities Research Programme. London: City University. http://www.coe.int/t/dg4/cultureheritage/culture/cities/ICCFinal Reportv2_en.pdf

Barn, G. 2011. Making the Most of Diversity - Profile of Intercultural Innovators. Strasbourg: Council of Europe. http://www.coe.int/t/dg4/cultureheritage/culture/cities/ newsletter/newsletter16/innovator_EN.asp

Barrett, M., ed. 2013. Interculturalism and Multiculturalism: Similarities and Differences. Strasbourg: Council of Europe Publishing.

Barry, B. 2001. Culture and Equality: An Egalitarian Critique of Multiculturalism. Cambridge, MA: Harvard University Press. 
Bennett, T., ed. 2001. Differing Diversities: Transversal Study on the Theme of Cultural Policy and Cultural Diversity. Strasbourg: Council of Europe.

Blommaert, J. and J. Verschueren. 1998. Debating Diversity: Analyzing the Discourse of Tolerance. London: Routledge.

Bloomfield, J., and F. Bianchini. 2001. "Cultural Citizenship and Urban Governance in Western Europa." In Culture and Citizenship, edited by N. Stevenson, 99-123. London: Sage.

Bloomfield, J., and F. Bianchini. 2004. Planning for the Intercultural City. Stroud: Comedia.

Borkert, M., W. Bosswick, F. Heckmann, and D. Lüken-Klaben. 2007. Local Integration Policies for Migrants in Europe. Luxembourg: Office for Official Publications of the European Communities VIII.

Bouchard, G. 2011. "What is Interculturalism." McGill Law Journal / Revue de droit de McGill 56 (2): 435-468. http://lawjournal.mcgill.ca/userfiles/other/2710852-Bouchard_e.pdf.

Bouchard, G. 2012. L'interculturalisme: un point de vue quebecois. Montréal: Boréal.

Bouchard, G., and C. Taylor. 2008. Building the Future, a Time for Reconciliation, Abridged Report. Quebec: The Consultation Commission on Accommodation Practices Related to Cultural Difference.

Brecknock, R. 2006. Planning and Designing Culturally: More than Just a Bridge. London: Comedia.

Brecknock, R., M. Caust, A. Howell, and C. Landry. 2007. Knowing Lewisham. Bournes Green: Comedia. http://www.coe.int/t/dg4/cultureheritage/culture/cities/Publication/ Lewisham.pdf

Brubaker, R. 2002. "Ethnicity without Groups." European Journal of Sociology 43 (2): 163-189. doi:10.1017/S0003975602001066.

Brunson, P. R. 2013. "Building Intercultural Strategies with Citizens - The Results-Based Accountability Approach." Council Europe. Accessed December 10. http://www.coe. int/t/dg4/cultureheritage/culture/Cities/Publication/Handbook-designing.pdf

Cantle, T. 2001. Community Cohesion: Report of the Independent Review Team - The 'Cantle Report'. London: Home Office.

Cantle, T. 2008. Community Cohesion: A New Framework for Race and Diversity. London: Palgrave.

Cantle, T. 2012. Interculturalism: The New Era of Cohesion and Diversity. London: Palgrave.

Caponio, T. 2009. Intercultural Policies and Intergroup Relations. Case Study: Valencia, Spain. Dublin: Eurofound.

Clarijs, R., C. Hogan, P. Wood, I. Guidikova, M. Doolan, T. Malmberg, R. Barn, et al. 2011. "Diversity and Community Development: An Intercultural Approach." Editor SWP. Accessed December 10. http://www.coe.int/t/dg4/cultureheritage/culture/cities/ Publication/community en.asp

Comedia. 2010. Helsinki is an Open and Intercultural City. Stroud: Comedia.

Council of Europe. 2008. Living Together As Equals in Dignity, White Paper on Intercultural Dialogue. Strasbourg: Council of Europe.

Council of Europe. 2011. "Living Together - Combining Diversity and Freedom in 21st Century Europe." Accessed December 9. www.coe.int

Council of the European Union. 2010. European Ministerial Conference on Integration, Declaration 8771/10, Zaragoza, April 15-16.

Crawly, H., and T. Crimes. 2009. Intercultural Policies and Intergroup Relations. Case Study: Malmoe, Sweden. Dublin: Eurofound.

Emerson, M., ed. 2011. Interculturalism: Europe and Its Muslims in Search of Sound Societal Models. Brussels: Centre for European Policy Studies paperbacks. 
Faist, T. 2009. "Diversity - a New Mode of Incorporation?" Ethnic and Racial Studies 32 (1): 171-190. doi:10.1080/01419870802483650.

Farrar, M., S. Robinson, and O. Sener. 2012. "Interculturalism in Europe: Fact, Fad or Fiction - the Deconstruction of a Theoretical Idea in Debating Multiculturalism 1." In Unedited Workshop Proceedings: Debating Multiculturalism 1, 101-110. Accessed December 9. http://www.dialoguesociety.org/leeds-discussion-forums/658-academicworkshop-call-for-papers-debating-multiculturalism.html\#.VIbu7GeOonc

Festenstein, M. 2005. Negotiating Diversity: Culture, Deliberation, Trust. Cambridge: Polity.

Frazer, N., and A. Honneth. 2003. Redistribution or Recognition? A PoliticalPhilosophical Exchange. London: Verso Books.

Friedrich, K. 1972. Tradition and Authority. London: Macmillan.

Goodhart, D. 2004. "Too Diverse.” Prospects Magazine, February 20. http://www.prospectmagazine.co.uk/magazine/too-diverse-david-goodhart-multiculturalism-britainimmigration-globalisation/

Gruescu, S., and V. Menne. 2010. Bridging Differences: What Communities and Government Can Do to Foster Social Capital. London: The Social Market Foundation.

Gundara, J. S., and S. Jacobs, eds. 2000. Intercultural Europe: Diversity and Social Policy. Aldershot: Ashgate.

Hall, S. 2000. "Conclusion: The Multicultural Question.” In Unsettled Multiculturalisms: Diasporas, Entanglements, Transruptions, edited by B. Hesse. London: Zed Books.

Hewstone, M., N. Tausch, J. Hughes, and E. Cairns. 2007. "Prejudice, Intergroup Contact and Identity: Do Neighbourhoods Matter?" In Identity, Ethnic Diversity and Community Cohesion, edited by M. Wetherell, M. Lafleche, and R. Berkeley, 102113. London: Sage.

Hogan, C. 2011. "Diversity in Harmony in European Cities: Connecting Social Improvement and Their Measurements in the Real World." In Diversity and Community Development: An Intercultural Approach, edited by M. A. J. L. Clarijs and I. Guidikova. Amsterdam: SWP. Accessed December 9. http://www.coe.int/t/dg4/cultureheritage/culture/cities/ Publication/community_en.asp

Howarth, C., and E. Andreouli. 2012. "Has Multiculturalism Failed? The Importance of Lay Knowledge and Everyday Practice." Institute of Social Psychology Research Paper, The London School of Economics and Political Science Publications. http:// www2.lse.ac.uk/socialPsychology/faculty/caroline_howarth/Howarth-and-Andreoulipaper-FINAL.pdf

Hussain, A., B. Law and T. Haq. 2006. Engagement with Culture: From Diversity to Interculturalism. Leicester: University of Leicester, Vaughan Papers 41

Khan, N. 2006. The Road to Interculturalism: Tracking the Arts in a Changing World. London: Comedia.

Kymlicka, W. 1995. Multicultural Citizenship: A Liberal Theory of Minority Rights. Oxford: Oxford University Press.

Kymlicka, W. 2003. "Multicultural States and Intercultural Citizens." Theory and Research in Education 1 (2): 147-169. doi:10.1177/1477878503001002001.

Lüken-Klaßen, D., and F. Heckmann. 2010. Intercultural Policies in European Cities. Report European network of cities for local integration policies for migrants (CLIP). Dublin: Eurofound.

Matusz Protasiewicz, P. 2009a. Intercultural Policies and Intergroup Relations. Case Study: Tallin, Estonia. Dublin: Eurofound.

Matusz Protasiewicz, P. 2009b. Intercultural Policies and Intergroup Relations. Case Study: Wroclaw, Poland. Dublin: Eurofound. 
Meer, N., and T. Modood. 2012. "How does Interculturalism Contrast with Multiculturalism?" Journal of Intercultural Studies 33 (2): 175-196. doi:10.1080/ 07256868.2011.618266.

Meer, N., T. Modood, and R. Zapata-Barrero, eds. forthcoming. Multiculturalism versus Interculturalism: Debating the Dividing Lines. Edinburgh: Edinburgh University Press (provisional title, scheduled publication date: January 2016).

Miller, D. 2008. "Immigrants, Nations and Citizenship." Journal of Political Philosophy 16: 371-390. doi:10.1111/j.1467-9760.2007.00295.x.

Modood, T. 2010. Still Not Easy Being British: Struggles for a Multicultural Citizenship. Oakhill: Trentham Books.

Page, S. E. 2007. The Difference: How the Power of Diversity Creates Better Groups, Firms, Schools and Societies. Princeton, NJ: Princeton University Press.

Pakulski, J., and S. Markowski, eds. 2014. Globalisation, Immigration and Multiculturalism - The European and Australian Experiences (Special issue). Journal of Sociology 50 (1): 3-9. doi:10.1177/1440783314522186.

Parekh, B. 2000. Rethinking Multiculturalism: Cultural Diversity and Political Theory. London: MacMillan.

Phillips, A. 2007. Multiculturalism Without Culture. Princeton, NJ: Princeton University Press.

Putnam, R. D. 2007. "E Pluribus Unum: Diversity and Community in the Twenty-First Century the 2006 Johan Skytte Prize Lecture.” Scandinavian Political Studies 30 (2): 137-174. doi:10.1111/j.1467-9477.2007.00176.x.

Ricucci, R. 2009. Turin. CLIP Report. Turin: FIERI.

Sandercock, L. 2004. "Reconsidering Multiculturalism: Towards an Intercultural Project." In Intercultural City Reader, edited by P. Wood, 16-21. London: Comedia.

Sandercock, L. 2009. "Towards a Cosmopolitan Urbanism: From Theory to Practice." In Where Strangers Become Neighbours: Integrating Immigrants in Vancouver, Canada, edited by L. Sandercock and G. Attili, 193-232. London: Springer.

Sen, A. 1992. Inequality Reexamined. Oxford: Clarendon Press.

Sze, F., and D. Powell, eds. 2004. Interculturalism: Exploring Critical Issues. Oxford: Interdisciplinary Press.

Taylor, C. 2012. "Interculturalism or Multiculturalism?" Philosophy and Social Criticism 38 (4-5): 413-423. doi:10.1177/0191453711435656.

Turner, B. 2001. "Outline of a General Theory of Citizenship." In Culture and Citizenship, edited by N. Stevenson, 11-32. London: Sage.

van Heelsum, A. 2010. Intercultural Policies and Intergroup Relations. Case Study: Amsterdam, the Netherlands. Dublin: Eurofound.

Vertovec, S. 2007. "Super-Diversity and Its Implications." Ethnic and Racial Studies 30 (6): 1024-1054. doi:10.1080/01419870701599465.

Vertovec, S., ed. 2014. Migration and Diversity. Cheltenham: Edward Elgar.

Vertovec, S., and S. Wessendorf, eds. 2009. Backlash against Multiculturalism in Europe: Public Discourse, Policies and Practices. Londres: Routledge.

Weber, M. 1968. Economy and Society: An Outline of Interpretive Sociology. Berkeley: University California Press.

Wood, P. 2004. The Intercultural City Reader. Stroud: Comedia.

Wood, P. forthcoming. "Meet Me on the Corner? Shaping the Conditions for CrossCultural Interaction in Urban Public Space." In Interculturalism in Cities: Concept, Policy and Implementation, edited by R. Zapata-Barrero. Cheltenham: Edward-Elgar (forthcoming in March 2015).

Wood, P. and C. Landry. 2008. The Intercultural City: Planning for Diversity Advantage. London: Earthscan. 
Wood, P., C. Landry, and J. Bloomfield. 2006. Cultural Diversity in Britain: A Toolkit for Cross-cultural Cooperation. London: Joseph Rowntree Foundation.

Zachary, G. P. 2003. The Diversity Advantage: Multicultural Identity in the New World Economy. Boulder, CO: Westview.

Zapata-Barrero, R. 2011. "Anti-Immigration Populism: Can Local Intercultural Policies Close the Space?." Discussion Paper, Policy Network. http://dcpis.upf.edu/ ricardzapata/ ricardzapata/Policynetwork.interculturalism.discussion.paper-1.pdf

Zapata-Barrero, R. 2014. "The Limits to Shaping Diversity as Public Culture: Permanent Festivities in Barcelona." Cities: The international Journal of Urban Policy and Planning 37: 66-72. doi:10.1016/j.cities.2013.11.007.

Zapata-Barrero, R. forthcoming. "Introduction: Framing the Intercultural Turn." In Interculturalism in Cities: Concept, Policy and Implementation, edited by $\mathrm{Z}$. Barrero. Cheltenham: Edward-Elgar (forthcoming in March 2015).

RICARD ZAPATA-BARRERO is Professor and Director of GRITIM-UPF in the Department of Social and Political Science at Universitat Pompeu Fabra (Barcelona, Catalonia, Spain)

ADDRESS: Department of Social and Political Science, Universitat Pompeu Fabra, Ramon Trias Fargas, 25-27 - 08005. Barcelona (Catalonia, Spain)

Email: ricard.zapata@upf.edu

Website: http://dcpis.upf.edu/ ricard-zapata/ 